\title{
Association of Myeloperoxidase Gene Functional Variant with Schizophrenia and Smoking in a Turkish Population
}

\section{Türk Toplumunda Myeloperoksidaz Geni Fonksiyonel Varyantının Sizofreni ve Sigara ile ilişkisi}

\section{Sacide Pehlivan ${ }^{1} \oplus$, Pınar Cetinay Aydin ${ }^{2} \oplus$, Mehmet Atilla Uysal ${ }^{3} \oplus$, Ayse Feyda Nursal ${ }^{4} \oplus$, Selin Kurnaz $z^{1 \oplus}$ Ulgen Sever ${ }^{1 \oplus}$, Aybike Aydin ${ }^{2 \oplus}$, Nazan Aydin $^{2 \oplus}$, Mustafa Pehlivan ${ }^{5 \oplus}$}

${ }^{1}$ Department of Medical Biology, Istanbul Faculty of Medicine, Istanbul University, Istanbul, Turkey

${ }^{2}$ Department of Psychiatry, Bakirkoy Prof. Dr. Mazhar Osman Mental Health and Neurological Diseases Research and Training Hospital, Istanbul, Turkey

${ }^{3}$ Department of Chest Diseases, Yedikule Hospital for Chest Diseases and Thoracic Surgery Training and Research Hospital, University of Health Sciences, Istanbul, Turkey

${ }^{4}$ Department of Medical Genetics, Faculty of Medicine, Hitit University, Corum, Turkey

${ }^{5}$ Department of Hematology, Faculty of Medicine, Gaziantep University, Gaziantep, Turkey

Received: 20.05.2020 / Accepted: 28.07.2020 / Published Online: 30.09.2020

Cite as: Pehlivan S, Çetinkay Aydın P, Atilla Uysal M, Nursal AF, Kurnaz S, Sever U, Aydın A, et al. Assessment of knowledge levels of nurses working in surgical clinics about ERAS protocol. Med J Bakirkoy 2020;16(3):197-202.

\begin{abstract}
Objective: Etiopathogenesis of schizophrenia (SCZ) involves several risk genes that induce inflammation, environmental stress factors and changes in the innate immune system. Patients with SCZ have the highest rate of cigarette smoking and severe nicotine dependence. Myeloperoxidase (MPO), a member of subfamily of peroxidases, is most abundantly expressed in immune cells. The aim of this study was to investigate the relationship between the MPO rs2333227 variant and SCZ/smoking etiopathogenesis.

Method: The study included 54 patients with SCZ, 94 smokers and 92 healthy controls. MPO rs2333227 variant was genotyped by polymerase chain reaction- restriction fragment length polymorphism (PCR-RFLP) method. Odds ratio (OR) and 95\% confidence interval (95\%CI) were calculated using the $\chi^{2}$ test.

Results: $G / G$ and $G / A$ genotypes of MPO rs2333227 were detected in our study samples. The frequencies of the $G / G$ and $G / A$ genotypes were 53.7\%, 46.3\%; 56.3\%; 43.7\%; 68.9\%, 31.1\% in SCZ patients, smokers, and the control group, respectively. The allele frequencies were G: $76.9 \%$ (SCZ patients), $77.4 \%$ (smokers) 83.7\% (controls); A: 23.1\% (SCZ patients), 22.6\% (smokers), and 16.3\% (controls). There was no significant difference between the SCZ patients, smokers and controls regarding MPO rs2333227 variant either in terms of allele frequency or genotype frequency. Then we genotyped the groups as women and men. MPO rs2333227 variant genotype distribution did not differ between men and women ( $p>0.05$ ).

Conclusion: This study does not support the role of MPO rs2333227 variant in increasing genetic risk for SCZ/smoking in Turkish population.
\end{abstract}

Keywords: schizophrenia, smoking, myeloperoxidase, variant

öz

Amaç: Şizofreni (SCZ) etyopatogenezi, enflamasyon, çevresel stres faktörleri ve doğal bağışıklık sistemindeki değişiklikleri indükleyen çeşitli risk genlerini içerir. SCZ'li hastalar yüksek sigara içme oranına ve şiddetli nikotin bağımlılığına sahiptir. Peroksidaz alt familyasının bir üyesi olan miyeloperoksidaz (MPO), en çok bağışıklık hücrelerinde eksprese edilir. Bu çalışmanın amacı MPO rs2333227 varyantı ile SCZ/sigara içimi etyopatogenezi arasındaki ilişkiyi araştırmaktır.

Yöntem: Çalıșmaya 54 SCZ hastası, 94 sigara içen ve 92 sağlıklı kontrol dahil edildi. MPO rs2333227 varyantı polimeraz zincir reaksiyonusınırlayıcı enzim parça uzunluk polimorfizmi (PZR-RFLP) yöntemi ile genotiplendi. OR ve \%95Cl güven aralığı X2 testi kullanılarak hesaplandı. Bulgular: Çalışmada hemşirelerin \%84.25'i “ERAS protokolünü bilmediklerini, \%88,97'si çalıştıkları klinikte ERAS protokolü uygulamalarına yer verilmediğini, \%99,21'i ise "ERAS protokolüne yönelik herhangi bir yayını takip etmediğini, \%99,21'i ERAS protokolünü içeren herhangi bir eğitim almadığını belirtti.

Sonuç: Çalışma örneklerimizde MPO rs22333227 G/G ve G/A genotipleri saptandı. G/G ve G/A genotiplerinin sıklığı SCZ hastalarında, sigara içenlerde ve kontrol grubunda sırasıyla, \%53,7, \%46,3; \%56,3, \%43, 7; \%68,9, \%31,1 idi. Alel sıklıkları G: \%76,9 (SCZ hastaları), \%77,4 (sigara içenler), \%83,7 (kontroller); A \%23,1 (SCZ hastaları), \%22,6 (sigara içenler), \%16,3 (kontroller) idi. SCZ hastaları, sigara içenler ve kontroller arasında MPO rs2333227 varyantı alele frekansı ve genotip sıklığı açısından anlamlı bir fark yoktu. Sonra grupları kadın ve erkek olarak genotipledik. MPO rs22333227 varyant genotip dağılımı kadınlar ve erkekler arasında farklı değildi ( $p>0.05)$.

Anahtar kelimeler: şizofreni, sigara içimi, myeloperoksidaz, varyant

\section{Corresponding Author:}

feyda.nursal@gmail.com
S. Pehlivan 0000-0003-1272-5845

P. C. Aydin 0000-0002-1605-2724

M. A. Uysal 0000-0002-0430-498X
A. F. Nursal 0000-0001-7639-1122

S. Kurnaz 0000-0002-2038-4721

U. Sever 0000-0002-9754-0446
A. Aydin 0000-0001-7455-6333

N. Aydin 0000-0003-3232-7713

M. Pehlivan 0000-0002-6692-085X

(C) Telif hakkı Sağlık Bilimleri Üniversitesi Bakırköy Dr. Sadi Konuk Eğitim ve Araştırma Hastanesi'ne aittir. Logos Tıp Yayıncılık tarafindan yayınlanmaktadır. Bu dergide yayınlanan bütün makaleler Creative Commons Atff-GayriTicari 4.0 Uluslararası Lisansı ile lisanslanmıştır.

(c) Copyright Health Sciences University Bakırköy Sadi Konuk Training and Research Hospital. This journal published by Logos Medical Publishing.

Licenced by Creative Commons Attribution-NonCommercial 4.0 International (CC BY) 


\section{INTRODUCTION}

Schizophrenia (SCZ) is a common mental disease of unknown etiology that generally has onset in young adulthood and manifests several combinations of positive, and negative psychoticsymptoms, and cognitive impairment in attention and information processing ${ }^{(1)}$. The cause and pathogenesis of SCZ remain unclear. Many studies have reported that SCZ is caused by several risk factors that can be roughly classified into genetic factors and environmental factors. Hence, SCZ occurs as a result of an interaction between genes and the environment ${ }^{(2)}$. Relationships between the immune genes, such as those affecting the inflammatory response regulation and SCZ risk, have been revealed thanks to the advancements in molecular genetics ${ }^{(3)}$. Evidence supports that there are abnormalities of inflammatory markers in the blood, cerebrospinal fluid (CSF), and central nervous system (CNS), such as cytokines, leukocytes, acutephase reactants among the cases with $\mathrm{SCZ}^{(3)}$. It is well known that smoking leads to various physical health problems. It is the major cause of preventable death, since it enhances the risk of lung cancer and other malignancies ${ }^{(4)}$. Recently, there has been an increasing interest in tobacco smoking as a risk factor for SCZ spectrum disorders ${ }^{(5)}$. Some studies have reported that patients who had mental diseases were more than three times as likely to smoke compared to those without psychiatric disorders ${ }^{(6)}$. The studies have shown chronic inflammatory changes in smokers as compared to nonsmokers such as higher levels of leukotriene B4 and interleukin (IL)-6 and IL-8 ${ }^{(7)}$.

Myeloperoxidase (MPO) belongs to a subfamily of peroxidases. It is most commonly expressed in immune cells, including neutrophilic polymorphonuclear leukocytes (neutrophils) and lymphocytes monocytes, and macrophages and is also synthesized in other body cells ${ }^{(8)}$.

MPO has potent pro-inflammatory characteristics that facilitate the injury of tissue via inflammatory site oxidative damage. The MPO gene found in 17q23.1 encodes human MPO protein. The expression level or structure of the relevant protein may be changed with polymorphisms in the MPO gene ${ }^{(9)}$. At the promoter region of the MPO gene, polymorp- hism of rs2333227 (-463A/G) is found, binding with the site of SP1. The gene can be transcribed due to changes in the locus, hence affecting the MPO level ${ }^{(10)}$.

Therefore, this study aimed to investigate the genetic association between MPO rs2333227 variant and risk of SCZ and smoking in a Turkish cohort.

\section{MATERIALS and METHODS}

\section{Study population}

A total of 54 patients with SCZ+smoker, 94 smokers, and 92 gender and age-matched healthy individuals as controls were included in the study. The subjects referring to Istanbul, Turkey, Yedikule Hospital for Chest Diseases and Thoracic Surgery Training and Research Hospital and Bakirkoy Research and Training Psychiatry Hospital, Istanbul Turkey were included in the study. SCZ was clinically diagnosed by psychiatrists strictly based on DSM-IV criteria (Diagnostic and Statistical Manual of Mental Disorders, the fourth edition) ${ }^{(11)}$. The scores obtained from the Fagerström Test for Nicotine Dependence (FTND) and Heaviness of Smoking Index (HSI) were determined to evaluate the severity of smoking ${ }^{(22)}$. There was random recruitment of the healthy controls from the same hospital. The healthy subjects who had a psychiatric problem in their life, any serious endocrine or neurological disorder, those who received any treatment or underwent medical condition affecting the brain, and mental retardation determined based on the patient version of the Structured Clinical Interview for DSM-IV-TR Axis I Disorders were excluded from the study. Also, the control group of patients did not smoke. All participants belonged to the Turkish population in Turkey. The patients submitted the informed, written consent. There was anonymous information about the patient before submission. Local Ethics Committee approved the work. All the procedures which were performed for the study followed the Declaration of Helsinki.

\section{Genotyping}

Samples of peripheral blood were taken from all participants.Tthe genomic DNA was extracted from peripheral venous blood sample treated by EDTA (ethylenediamine tetraacetate) with the salting-out method ${ }^{(13)}$, and it was stored at $-20^{\circ} \mathrm{C}$ until the time of analysis. MPO rs2333227 variant was genotyped 
using the polymerase chain reaction-restriction fragment length polymorphism (PCR-RFLP) method described in a previous study ${ }^{(14)}$. G/G and $G / A$ genotypes of MPO rs2333227 were detected in our study samples.

\section{Statistical analysis}

Software SPSS version 20.0 (SPSS Inc., Chicago, IL, USA) for Windows was used to analyze all data. The statistically significant differences between the controls and cases were estimated by logistic regression analysis. Odds ratio (OR) and $95 \%$ confidence interval $(\mathrm{Cl})$ were also calculated. Chi-square test was used to compare the differences in MPO rs2333227 variant genotype and allele frequencies between cases and controls, and if necessary, the Fisher's exact test was used. Two-tailed analyses were done, and $p<0.05$ showed statistically significant differences.

\section{RESULTS}

For MPO rs2333227 variant, 54 SCZ+smoker patients (41 females, 13 males), 94 smokers (43 females, 51 males), and 92 controls ( 55 females, 37 males) were evaluated. The groups had the allele and genotype distributions of MPO rs2333227, as shown in Table 1. G/G and G/A genotypes of MPO rs2333227 were detected in our study samples. The frequencies of the $\mathrm{G} / \mathrm{G}$ and $\mathrm{G} / \mathrm{A}$ genotypes were $53.7 \%, 46.3 \%$; $56.3 \% ; 43.7 \%$; $68.9 \%, 31.1 \%$ in SCZ patients, smokers, and the control group, respectively. The allele frequencies were G: $76.9 \%, 77.4 \% 83.7 \%$; A: $23.1 \%$, $22.6 \%$, and $16.3 \%$. There was no significant difference between the SCZ patients, smokers, and controls regarding the MPO rs 2333227 variant either in terms of allele or genotype frequencies.
Then we genotyped the groups into women and men. The distribution of MPO rs2333227 variant genotype did not differ between male and male patients ( $p>0.05)$ (Data not shown).

\section{DISCUSSION}

Cells and mediators which have evolved mainly to defend humans against malignancy and infection have been complexly organized in the immune system. Complex interactions between the immune system and brain influencing neural function, survival, and development may be etiologically and therapeutically associated for numerous CNS diseases such as psychiatric diseases ${ }^{(15)}$. SCZ is seen in about $1 \%$ of the population during their lives and mainly starts when the brain develops following puberty ${ }^{(16)}$.

There was a suggestion of a possible relationship between the immune system and SCZ about one century ago, which was confirmed by epidemiological studies finding relations with systemic inflammation and infection. There is a relationship between autoimmune conditions during childhood and subclinical psychotic episodes in adolescents and SCZ in adults ${ }^{(17)}$. Also, there is a linear increase in the risk of SCZ by increasing the number of severe infections among the individuals who previously had a history of autoimmune disease (17). An immune-mediated etiology SCZ was supported by the studies on genome association, suggesting significant links between markers near the region of major histocompatibility complex (MHC) and the SCZ on chromosome $6^{(18)}$. Besides, this disease is significantly associated with enhancers having a potent role in the immune functions, even after excluding the $\mathrm{MHC}$ region genes ${ }^{(19)}$. Moreover, at least two ILs seem to be involved in the

Table 1. Genotype distribution and allele frequencies of MPO rs2333227 variant in groups.

\begin{tabular}{|c|c|c|c|c|c|c|}
\hline MPO rs2333227 & SCZ group & Smoker group & Control group & OR* & $\% 95 \mathrm{Cl}^{*}$ & $\mathbf{P}$ \\
\hline Genotypes & $n=54(\%)$ & $n=94(\%)$ & $n=92(\%)$ & & & \\
\hline $\mathrm{G} / \mathrm{G}$ & $29(53.7)$ & $53(56.3)$ & 62 (68.9) & $0.561^{a}$ & $0.282-1.119^{a}$ & $0.113^{a}$ \\
\hline \multirow[t]{2}{*}{$\mathrm{G} / \mathrm{A}$} & 25 (46.3) & 41 (43.7) & $30(31.1)$ & $0.625^{b}$ & $0.344-1.136^{b}$ & $0.133^{b}$ \\
\hline & & & & $0.897^{c}$ & $0.458-1.758^{c}$ & $0.864^{c}$ \\
\hline Alleles & & & & $0.647^{a}$ & $0.357-1.172^{a}$ & $0.164^{a}$ \\
\hline G & 83 (76.9) & $147(77.4)$ & 154 (83.7) & $0.698^{b}$ & $0.414-1.178^{b}$ & $0.189^{b}$ \\
\hline$A$ & $25(23.1)$ & $41(22.6)$ & $30(16.3)$ & $0.926^{c}$ & $0.526-1.630^{c}$ & $0.885^{c}$ \\
\hline
\end{tabular}

${ }^{*}$ Fisher's Exact Test, ${ }^{a}$ : Sch group versus control group, ${ }^{b}:$ Smoker group versus control group, ${ }^{c}$ : Sch group versus smoker group. 
impacts on systems of neurotransmitter in SCZ: IL-1 $\beta$, which promotes mesencephalic progenitor cells of rat converted into a dopaminergic phenotype, and IL- 6 , which shortens survival of serotonergic neurons in the fetus ${ }^{(20)}$. This association in humans can be supported by a cohort study of bacterial infections and studies on some infections. A higher risk for SCZ may be due to higher levels of C-reactive protein and cytokines during childhood ${ }^{(20)}$.

The inflammatory markers in a vascular wall may be activated by the endothelial dysfunction induced by smoking ${ }^{(21)}$. Some studies have demonstrated that C-reactive protein with high sensitivity, plasma viscosity, several inflammatory markers, their serum concentrations, and fibrinogen are affected by smoking, and elevated slightly in ex-smokers. There is a positive correlation between duration of smoking and inflammation markers. On the contrary, there is also an inverse relationship between inflammation markers and the time elapsed after quitting smoking ${ }^{(22)}$.

The lysosomal enzyme and peroxidase activity were analyzed in the MPO ${ }^{23)}$, which plays a role in the regulation of inflammatory responses, Iysosomal pathway, tissue damage, lipid metabolism, and oxidative damage ${ }^{(24)}$. Not only is MPO activity engaged in the host defense physiology against microorganisms, but also it is involved in the pathophysiology of atherosclerosis, respiratory tract and CNS diseases, and cardiac dysfunction ${ }^{(25)}$. High levels of MPO have been detected in brain tissue, in some neurodegenerative disorders. There have been significantly higher MPO protein levels in Huntington's disease and Parkinson's disease in the samples of caudate and nucleus midbrain, respectively while there were no differences MPO protein contents in motor cortex samples in amyotrophic lateral sclerosis as compared to controls (26).

In a twin study, twins with a history of major depressive disorder had $32 \%$ higher blood levels of MPO (27). Another study revealed that those suffering from comorbidity of hyperactivity disorder /attention deficit and bipolar disorder had significantly higher mean MPO levels than a bipolar disorder (28). But Kartalci et al. found no significant association between the SCZ patient and control groups as for MPO levels ${ }^{(29)}$. It has been also revealed that the levels of
MPO are elevated significantly in smokers compared with nonsmokers ${ }^{(30,31)}$.

The MPO gene encodes for a single translational product that, after glycosylation and proteolytic processing, is released as mature MPO in the azurophilic granules ${ }^{(32)}$. It was reported that MPO transcriptional activity could be positively enhanced by binding reversibly to the SP1 transcription factor due to a noticeable functional polymorphism in which there was an exchange of $\mathrm{G}$ to $\mathrm{A}$ base at -463 ( $\mathrm{rs} 2333227$ ) in the promoter region ${ }^{(33)}$. There is an SP1 binding the MPO -463G variant, activating 25-fold transcription in transient transfection assays, whereas the MPO -463A allele leads to notably less transcriptional activity ${ }^{(33)}$. The variant of MPO rs2333227 variant has been described as a protective genetic factor against development of several malignancies. It seems that the genotypes of A/A and MPO -463G/A have a diminished risk of colorectal adenomas, acute leukemia, gastric, lung, and ovarian carcinoma ${ }^{(32)}$. Ji et al. found MPO rs2333227 variant was positively associated with the risk of Alzheimer's disease among the population in China ${ }^{(24)}$. Galecki et al. declared a statistically significant difference in genotype distribution and allele frequency of MPO rs2333227 variants between depressive patients and healthy controls ${ }^{(34)}$.

This study was conducted to elucidate the genetic role of the MPO rs2333227 variant in SCZ and smoking status. No association was observed in the analysis of SCZ/smoking and this variant in our population. There are some limitations in this study. There is no large sample size in the study, and only one Turkish cohort was included in the study group. Furthermore, the study did not consider the relationship between MPO polymorphisms and other factors, such as environmental factors.

\section{CONCLUSIONS}

In summary, as far as we know, the present study is the first one that examines the association between the MPO rs2333227 variant with SCZ and smoking among the population in Turkey. No evidence of an association between MPO rs2333227 variant with SCZ and smoking was observed in this sample of the Turkish population. Due to these limitations, the role 
of MPO promoter variant in SCZ/smoking status in the future should be clarified by conducing further larger-scale studies which are well designed on multiple populations.

Ethics Committee Approval: Approval was obtained from the Istanbul Medical Faculty Clinical Research Ethics Committee $(09,10,2015$ / 17).

Conflict of interest: The authors have declared no conflict of interest, financial or otherwise.

Funding: The study was partially supported by Istanbul University ONAP-BAP (47815) program.

Informed Consent: Informed consent was obtained from all individual participants included in the study.

\section{REFERENCES}

1. Hennah W, Thomson P, Peltonen L, Porteous D. Genes and schizophrenia: beyond schizophrenia: the role of DISC1 in major mental illness. Schizophr Bull. 2006;32(3):409-16.

https://doi.org/10.1093/schbul/sbj079

2. Lichtenstein P, Yip BH, Bjork C, Pawitan Y, Cannon TD, Sullivan PF, et al. Common genetic determinants of schizophrenia and bipolar disorder in Swedish families: a population-based study. Lancet. 2009;373(9659): 234-9. https://doi.org/10.1016/S0140-6736(09)60072-6

3. Miller BJ, Goldsmith DR. Inflammatory biomarkers in schizophrenia: Implications for heterogeneity and neurobiology. Biomarkers in Neuropsychiatry. 2019;1: 100006.

https://doi.org/10.1016/j.bionps.2019.100006

4. Collaborators GT. Smoking prevalence and attributable disease burden in 195 countries and territories, 19902015: a systematic analysis from the Global Burden of Disease Study 2015. Lancet. 2017;389(10082):1885906.

https://doi.org/10.1016/S0140-6736(17)30819-X

5. Hunter A, Murray R, Asher L, Leonardi-Bee J. The Effects of Tobacco Smoking, and Prenatal Tobacco Smoke Exposure, on Risk of Schizophrenia: A Systematic Review and Meta-Analysis. Nicotine Tob Res. 2020;22(1):3-10. https://doi.org/10.1093/ntr/nty160

6. Dickerson F, Schroeder J, Katsafanas E, Khushalani S, Origoni $A E$, Savage $C$, et al. Cigarette smoking by patients with serious mental illness, 1999-2016: an increasing disparity. Psychiatr Serv. 2018;69(2):147-53. https://doi.org/10.1176/appi.ps.201700118

7. Mazur W, Stark H, Sovijarvi A, Myllarniemi M, Kinnula VL. Comparison of 8-isoprostane and interleukin-8 in induced sputum and exhaled breath condensate from asymptomatic and symptomatic smokers. Respiration. 2009;78(2):209-16.

https://doi.org/10.1159/000206010

8. Khan AA, Alsahli MA, Rahmani AH. Myeloperoxidase as an Active Disease Biomarker: Recent Biochemical and Pathological Perspectives. Med Sci (Basel). 2018;6(2): 33. https://doi.org/10.3390/medsci6020033

9. Rudolph V, Rudolph TK, Kubala L, Clauberg N, Maas R, Pekarova $\mathrm{M}$, et al. A myeloperoxidase promoter polymorphism is independently associated with mortality in patients with impaired left ventricular function. Free Radic Biol Med. 2009;47(11):1584-90.

https://doi.org/10.1016/j.freeradbiomed.2009.09.001

10. Hansson M, Olsson I, Nauseef WM. Biosynthesis, processing, and sorting of human myeloperoxidase. Arch Biochem Biophys. 2006;445(2):214-24. https://doi.org/10.1016/j.abb.2005.08.009

11. American Psychiatric Association. Diagnostic and statistical manual of mental disorders. Text Revision. 4th. Washington (DC): American Psychiatric Association; 2000.

12. Heatherton TF, Kozlowski LT, Frecker RC, Fagerström K. The Fagerström test for nicotine dependence: a revision of the Fagerström tolerance questionnaire. $\mathrm{Br} \mathrm{J}$ Addict. 1991;86(9):1119-27. https://doi.org/10.1111/j.1360-0443.1991.tb01879.x

13. Miller SA, Dykes DD, Polesky HF. A simple salting out procedure for extracting DNA from human nucleated cells. Nucleic Acids Res. 1988;16(3):1215. https://doi.org/10.1093/nar/16.3.1215

14. Erciyas K, Pehlivan S, Sever T, Orbak R. Genetic Variation of Myeloperoxidase Gene Contributes to Aggressive Periodontitis: A Preliminary Association Study in Turkish Population. Dis Markers. 2010;28(2):95-9. https://doi.org/10.1155/2010/734619

15. Khandaker GM, Pearson RM, Zammit S, Lewis G, Jones PB. Association of serum interleukin- 6 and c-reactive protein in childhood with depression and psychosis in young adult life: a population-based longitdunal study. JAMA Psychiatry. 2014;71(10):1121-8.

https://doi.org/10.1001/jamapsychiatry.2014.1332

16. Kirkbride JB, Errazuriz A, Croudace TJ, Morgan C, Jackson D, Boydell J, et al. Incidence of schizophrenia and other psychoses in England, 1950-2009: a systematic review and meta-analyses. PLoS One. 2012;7(3):e31660. https://doi.org/10.1371/journal.pone.0031660

17. Benros ME, Nielsen PR, Nordentoft M, Eaton WW, Dalton SO, Mortensen PB. Autoimmune diseases and severe infections as risk factors for schizophrenia: a 30-year population-based register study. Am J Psychiatry. 2011;168(12):1303-10. https://doi.org/10.1176/appi.ajp.2011.11030516

18. Shi J, Levinson DF, Duan J, Sanders AR, Zheng Y, Pe'er I, et al. Common variants on chromosome 6p22.1 are associated with schizophrenia. Nature. 2009; 460(7256):753-7. https://doi.org/10.1038/nature08192

19. Schizophrenia Working Group of the Psychiatric Genomics Consortium. Biological insights from 108 schizophrenia-associated genetic loci. Nature. 2014;511(7510):421-7. https://doi.org/10.1038/nature13595

20. Müller N. Inflammation in Schizophrenia: Pathogenetic Aspects and Therapeutic Considerations. Schizophr Bull. 2018;44(5):973-82. https://doi.org/10.1093/schbul/sby024 
21. Mizia-Stec K, Zahorska-Markiewicz B, Gasior Z. Cigarette smoking and inflammatory indices in coronary artery disease. Int J Cardiol. 2004;93(2-3):16974. https://doi.org/10.1016/S0167-5273(03)00198-0

22. Daloee MH, Avan A, Mirhafez SR, Kavousi E, HasanianMehr M, Darroudi S, et al. Impact of Cigarette Smoking on Serum Pro- and Anti-Inflammatory Cytokines and Growth Factors. Am J Mens Health. 2017;11(4):116973. https://doi.org/10.1177/1557988315601724

23. Perianayagam MC, Tighiouart $\mathrm{H}$, Liangos $\mathrm{O}$, Kouznetsov D, Wald R, Rao F, et al. Polymorphisms in the myeloperoxidase gene locus are associated with acute kidney injury-related outcomes. Kidney Int. 2012;82(8):90919. https://doi.org/10.1038/ki.2012.235

24. Ji W, Zhang Y. The association of MPO gene promoter polymorphisms with Alzheimer's disease risk in Chinese Han population. Oncotarget. 2017;8(64):107870-6. https://doi.org/10.18632/oncotarget.22330

25. Malle E, Furtmuller PG, Sattler W, Obinger C. Myeloperoxidase: a target for new drug development? Br J Pharmacol. 2007;152(6):838-54. https://doi.org/10.1038/sj.bjp.0707358

26. Gellhaar S, Sunnemark D, Eriksson H, Olson L, Galter D. Myeloperoxidase-immunoreactive cells are significantly increased in brain areas affected by neurodegeneration in Parkinson's and Alzheimer's disease. Cell Tissue Res. 2017;369(3):445-54. https://doi.org/10.1007/s00441-017-2626-8

27. Vaccarino V, Brennan ML, Miller AH, Bremner JD, Ritchie JC, Lindau F, et al. Association of Major Depressive Disorder with Serum Myeloperoxidase and other Markers of Inflammation: A Twin Study. Biol Psychiatry. 2008;64(6):476-83. https://doi.org/10.1016/j.biopsych.2008.04.023

28. Aksoy N, Saygili El, Bulbul F, Bahar A, Savas H, Virit O, et al. Myeloperoxidase enzyme levels and oxidative stress in bipolar disorders. African Journal of Biotechnology. 2010;9 (22):3318-23. Available from: https://www.ajol.info/index.php/ajb/article/ view/80663

29. Kartalci S, Erbay LG, Zayman EP, Otlu O, Karabulut AB, Kartalci G. IL-4, TGF- ${ }^{\circledR}$, NF-|B and MPO Levels in Patients With Treatment Resistant Schizophrenia. Turk Psikiyatri Derg. 2016;27(3):170-5. Available from: http://www.turkpsikiyatri.com/Data/Unpublished Articles/4f9fo7.pdf https://doi.org/10.5080/u13642

30. Lavi S, Prasad A, Yang EH, Mathew V, Simari RD, Rihal $\mathrm{CS}$, et al. Smoking is associated with epicardial coronary endothelial dysfunction and elevated white blood cell count in patients with chest pain and early coronary artery disease. Circulation. 2007;115(20):2621-7. doi: 10.1161/CIRCULATIONAHA.106.641654. https://doi.org/10.1161/CIRCULATIONAHA.106.641654

31. Andelid K, Bake B, Rak S, Lindén A, Rosengren A, Ekberg-Jansson A. Myeloperoxidase as a Marker of Increasing Systemic Inflammation in Smokers Without Severe Airway Symptoms. Respir Med. 2007;101(5): 888-95. https://doi.org/10.1016/j.rmed.2006.09.023

32. Klebanoff SJ. Myeloperoxidase. Proc Assoc Am Physicians. 1999;111(5):383-9. https://doi.org/10.1111/paa.1999.111.5.383

33. Piedrafita FJ, Molander, RB Vansant, G Orlova, EA Pfahl, $M$ Reynolds, WF. An Alu element in the myeloperoxidase promoter contains a composite SP1-thyroid hormone-retinoic acid response element. J Biol Chem. 1996;271(24):14412-20. https://doi.org/10.1074/jbc.271.24.14412

34. Galecki P, Florkowski A, Bobińska K, Śmigielski J, Bieńkiewicz M, Szemraj J. Functional polymorphism of the myeloperoxidase gene (G-463A) in depressive patients. Acta Neuropsychiatr. 2010;22(5):218-22. https://doi.org/10.1111/j.1601-5215.2010.00483.x 